IRSTI 82.15.09

\author{
Nathan J. ${ }^{1}$, Kaliyeva S. ${ }^{2}$, Baisalova B. ${ }^{3}$ \\ ${ }^{1} \mathrm{PhD}$ Doctor, Professor, st. John`s University, USA, New York, e-mail: natjay@gmail.com \\ ${ }^{2}$ Chief researcher, Institute of Economics of SC MES RK, \\ Kazakhstan, Almaty, e-mail: kalievas_@mail.ru \\ ${ }^{3}$ Doctoral student, al-Farabi Kazakh National University, \\ Kazakhstan, Almaty, e-mail: baisalovab@gmail.com

\section{AGILE METHODOLOGY OF HUMAN CAPITAL MANAGEMENT}

Such topics as innovations, project management, and Agile are incredibly relevant in the context of scientific researches in the business community. However, an approach at the junction of these concepts not theoretically developed, as well as it turned out that there are not so many successful «best practices» of their correct usage and combining to obtain a cumulative synergetic effect. At the same time, the practice shows that many approaches to the agile philosophy are firmly rooted in mind and become an essential factor in the success of the projects and business initiatives. The purpose of this article is to study international experience in the implementation and application of methods of flexible human resources management. This article illustrates some of the profound changes that companies are making in their practices and describes the challenges they face in transitioning to flexible human resource management. Because HRM affects every aspect-and every employee-of the organization, its flexible transformation can be even more extensive (and more complex) than changes in other functions. Therefore, the following areas are considered: performance appraisal, training, team, independent decision-making, complex team dynamics, remuneration, recruitment, training and development, problems. It is shown that the introduction of a project management system is a necessary condition for the development of the company in a constantly changing environment. Due to the flexible approach to the implementation of the project management system, companies can develop a project management system for their needs and business needs. Particular attention is paid to the possibility of using flexible project management methodologies in different conditions. The obtained theoretical and practical results in the course of research can be used to expand the theoretical and methodological basis of the problem of the labor market and human capital management.

Key words: human capital, agile methodology, project management.

Натан Аж. ${ }^{1}$, Қалиева С. ${ }^{2}$, Байсалова Б. ${ }^{3}$

1PhD доктор, профессор, Әулие Ажон университеті, АҚШ, Нью-Йорк қ., е-mail: natjay@gmail.com Бас ғылыми қызметкер, ҚР БҒМ ҒК Экономика институты, Қазақстан, Алматы к., е-mail: kalievas @mail.ru ${ }^{3}$ Аокторант, әл-Фараби атындағы Қазақ, ұлттық университеті, Қазақстан, Алматы қ., e-mail: baisalovab@gmail.com

Адами капиталды басқарудың икемді әдіснамасы

Инновациялар, жобаларды басқару және икемділік тақырыптары ғылыми ізденістер мен бизнес-қоғамдастықта өте өзекті болып табылады. Алайда, осы облыстар тоғысындағы бағыттың теориялық әзірлемелілігі, кумулятивті синергетикалық, әсер алу мақсаттары үшін оларды дұрыс пайдалану мен біріктірудің табысты «best practices» сияқты тексеруге көп емес. Бұл ретте тәжірибе Agile философиясының көптеген тәсілдері сана-сезімде берік орнағанын және жобалар мен бизнес-бастамалар табысының маңызды факторына айналғанын көрсетеді. Бұл мақаланың мақсаты адам ресурстарын икемді басқару әдістерін енгізу мен қолданудың шетелдік тәжірибесін зерттеу болып табылады. Бұл мақалада компаниялар өз тәжірибесінде жасайтын және адам ресурстарын икемді басқаруға көшу кезінде кездесетін проблемалар сипатталған 
Agile methodology of human capital management

терең өзгерістердің кейбірі суреттелген. ТРК әрбір аспект және ұйымның әрбір қызметкерін қозғағандықтан, оның икемді трансформациясы басқа функциялардағы өзгерістерге қарағанда одан да кең (және одан да күрделі) болуы мүмкін. Сондықтан келесі салалар қаралды: қызметтік аттестаттау, тренингтер, командалар, өз бетінше шешім қабылдау, күрделі командалық Аинамика, сыйақы, қабылдау, оқыту және дамыту, проблемалар. Жобаларды басқару жүйесін енгізу компанияның тұрақты өзгермелі ортала дамуының қажетті шарты көрсетілген. Компания жобаларын басқару жүйесін енгізу кезінде икемді тәсілдің арқасында өз қажеттіліктері мен бизнес қажеттіліктеріне жобаларды басқару жүйесін дамытуы мүмкін. Әр түрлі жағдайларда жобаларды басқарудың икемді әдіснамасын пайдалану мүмкіндіктеріне ерекше назар аударылды. Алынған теориялық, және практикалық нәтижелер зерттеу барысында еңбек нарығы мен алам капиталын басқару мәселелерінің теориялық және әдіснамалық базасын кеңейтуде қолданылуы мүмкін.

Түйін сөздер: адам капиталы, икемді әдістеме, жобаларды басқару.

\author{
Натан Аж. ${ }^{1}$, Калиева С. ${ }^{2}$, Байсалова Б. ${ }^{3}$ \\ 1PhD доктор, профессор, Университет Святого Ажона, США, г. Нью-Йорк, e-mail: natjay@gmail.com \\ 2Главный научный сотрудник, Институт экономики КН МОН РК, \\ Казахстан, г. Алматы, e-mail: kalievas_@mail.ru \\ ${ }^{3}$ Аокторант, Казахский национальный университет имени аль-Фараби, \\ Казахстан, г. Алматы, e-mail: baisalovab@gmail.com
}

Гибкая методология управления человеческим капиталом

Тематики инноваций, управления проектами и гибкости являются крайне актуальными в контексте научных изысканий и бизнес-сообществе. ОАнако теоретической разработанности направления на стыке данных областей, равно как и успешных «best practices» их корректного использования и совмещения Аля целей получения кумулятивного синергетического эффекта, на поверку оказывается не так и много. При этом практика показывает, что многие подходы философии Agile уже прочно укоренились в сознании и становятся важным фактором успеха проектов и бизнес-инициатив. Целью данной статьи является исследование зарубежного опыта внедрения и применения методов гибкого управления человеческими ресурсами. В этой статье проил^юстрированы некоторые из глубоких изменений, которые компании делают в своей практике и описаны проблемы, с которыми они сталкиваются при переходе на гибкое управление человеческими ресурсами. Поскольку УЧР затрагивает каждый аспект и каждого сотрудника организации, его гибкая трансформация может быть еще более обширной (и более сложной), чем изменения в других функциях. Поэтому рассмотрены области: служебная аттестация, тренинги, команды, самостоятельное принятие решений, сложная командная динамика, вознаграждение, набор, обучение и развитие, проблемы. Показано, что внеАрение системы управления проектами - необходимое условие развития компании в постоянно изменяющемся окружении. Благодаря гибкому подходу при внеАрении системы управления проектами компании могут развивать систему управления проектами поА свои потребности и потребности бизнеса. Особое внимание УАелено возможностям использования гибких методологий управления проектами в различных условиях. Полученные теоретические и практические результаты в ходе исследований могут применяться в расширении теоретической и методологической баз проблемы рынка труда и управления человеческим капиталом.

Кмючевые слова: человеческий капитал, гибкие методологии, управление проектами.

\section{Introduction}

In recent decades, the theory and practice of human resource management have undergone radical changes. A new view of the labor force as one of the critical resources of any socio-economic system is approved. The basis of the concept of human resources management of a new organization is the increasing role of each employee, with his values, needs, aspirations, knowledge of his motivational attitudes, the ability to shape and guide them by the strategy of its development. Many prosperous companies in the world see this idea as economic content and strive to put it into practice.

The purpose of this article is to identify methods and tools of flexible human resources management, based on the experience of Western companies, comparison, and evaluation of their application in Kazakhstan's project-oriented companies.

The object of research: human resources are functioning in the system of organizational and economic relations of the modern organization.

The subject of research: agile methodology of human resources management 
The obtained theoretical and practical results in the course of study can be used to expand the theoretical and methodological basis of the problem of the labor market and human capital management.

In Kazakhstan, the agile implementation process is mainly used in its projects of a small number of organizations. In the public sector, these methods are not used, but there is a possibility of using Agile practices in the planning and budgeting of ICT projects. Organizations are increasing their interest in project management techniques. If earlier mainly used in the management of its projects, now more and more organizations consider this method as a method of control of the organization. Agile has already been launched in Sberbank of Kazakhstan, the Prosecutor General's office, the national welfare Fund of Samruk-Kazyna and its portfolio companies, Forte Bank, BI Group. Sberbank Kazakhstan is the first large corporate company in the market to announce the introduction of Agile approaches. The Bank began work on the transition to bimodal management within the organization. The agile approach is what the Bank actively invests in and considers it the key to future success.

The main task of the Agile approach in the Bank is to get the result faster, which is achieved through proper team building and work processes. The first step for the implementation of Agile in the Bank was to form a single correct view of the staff, what is Agile, or in the version of Sberbank - Sbergile (Sberbank). Sbergile is a new corporate culture, which serves to accelerate the interaction, which allows increasing collaboratively and responsibility at each level. All this is done to develop and bring new products and services to the market faster. The Sbergile process is in the implementation phase, and the Bank invests in understanding by inviting many coaches to give the team a clear vision of what it is and how it should work (Bahmutov, 2017: 172).

In many companies, this happens gradually, almost organically, as a side effect of IT, where more than $90 \%$ of organizations already use agile practices. For example, at the Bank of Montreal (BMO), the shift began with technical staff joining cross-functional product development teams to make the Bank more customer-oriented. The business side studied the principles of agile from its colleagues, as well as learned about the needs of customers from the business. One result is that BMO is now thinking about performance management in terms of teams, not just individuals. Many Kazakhstan's companies also apply the agile methodology in managing employees of the company, such as Henkel CAC attaches great importance to the opinion of specific specialists of the team, not only line managers when making management decisions. After all, the primary contact with the consumer of goods takes place at the level of sales representatives. And they can increase the level of efficiency through the initiation of their proposals and teamwork. Project teams respond flexibly to external changes, changing plans and responding to deviations promptly, considering the opinion and potential of team members. This method often practiced in national and foreign companies of Kazakhstan.

\section{Literature Review}

Elsewhere, the transition to agile HR was faster and more focused. GE is a Prime example. Considered for years as a model of management through management systems, it has moved to FastWorks, a lean approach that reduces financial control from top to bottom and gives teams the ability to manage projects as needs evolve. In Kazakhstan, most companies have long moved from bureaucracy to adhocracy - the organizational structure of most companies, except for some government agencies, schools and hospitals, adopted the principle of meritocracy. The personnel reserve has been enormously expanded, as everyone has the opportunity for career growth. The activities of each employee are not pursued and controlled by line managers. Construction company BI Group has found the application of Agile methodology in sales of apartments. Implementation of the technology began in December 2016. During this time, the app has brought positive results. The use of a flexible approach allows you to approach the sales of apartments individually. When the house is designed, it is not clear what apartments will be in demand from a potential buyer. Therefore, the company came to such a decision; while the house is being built, the layout can be changed by the wishes of buyers. They put the main supporting structure, and inside the planned design can be replaced by the demand for one or two-bedroom apartments.

Approach to Agile is in the combined form Kaizen + Agile. The company has a team of changes - drivers that move everyone forward. At the same time, the company has two departments: implementation and training. The training and implementation Department works together as cross-functional teams. It is going to the facilities conducting training, identifying problems and organizing groups to solve them. After the introduction of Agile methods, revenues and expenses of the organization significantly increased. 
One example is an application created by the Agile methods team. Following the Manifesto methodology, the application developers finished it within a month. So, applying the principle of uberization, any contractor BI Group can order in the mobile application construction equipment, which is currently free. Although under normal circumstances it would take 4-5 months. The national welfare Fund of Samruk-Kazyna implements and applies an Agile approach in the framework of the transition to the target model and the introduction of a new corporate culture. Agile values are included in the new benefits of the Fund, implemented in the framework of a separate project. The practice of developing solutions in cross functional Scrum teams has been introduced. The concept of internal clients, SLA practice and satisfaction surveys provided as part of the restructuring of the asset Optimization unit have been submitted. The organization of the Block's activities is moving to Agile principles. Digital Kanban boards are already used, daily stand-up meetings and weekly retrospectives are held. The application of the new approach will be expanded and consolidated, and the related units of the Fund will be gradually integrated into the new format of work. As part of the de-bureaucratization reduced the practice of working through the service. Messengers, outlook, personal meetings are used. Communication is much faster, which has a positive impact on the speed and quality of products and solutions.

Also, Agile-approaches are used in the organizations of Kazpost and Kazakhtelecom and other portfolio companies of the Fund. In General, the Fund systematically works to improve the efficiency and effectiveness of the organization with the use of available approaches and tools. In the Samruk-Kazyna Fund, Agile methods are used to manage the organization. In air Astana, despite the advanced operational activities, human resources management in the company is the best in the world. Their system has long overtaken many large companies. However, despite this indicator, the level of control of business processes over subordinates remains. This is a light indicator of how traditional plans and their implementation are the central aspects of business for many companies in Kazakhstan (Kaliyeva, 2014: 160). Now we are witnessing a more radical transformation. Why is this the right time? Because rapid innovation has become a strategic imperative for most companies, not just a subset. To do this, businesses are looking to Silicon Valley and software companies in particular by emulating their agile project management practices. In this way, top-down planning models give way to more agile, user-driven methods that are better suited for adaptation soon, such as rapid prototyping, iterative feedback, team decisions, and task-oriented sprints. As Lynn Roger, Director of BMO transformation, says, "speed is the new business currency" (Barney, 1995: 57). With the business case for old HR systems gone and a flexible playbook available to copy, people management is finally getting its long-awaited overhaul too. This article will illustrate some of the profound changes that companies are making in their talent practices, and describe the challenges they face in transitioning to agile HR. Where the most significant changes are taking place, because HR affects every aspect and every employee-of an organization, its flexible transformation can be even more extensive (and more complex) than changes in other functions.

\section{Materials and methods}

When enterprises adopted flexible methods in their core business, they abandoned the charade of trying to plan for a year or more ahead, how projects would go and when they would end. Thus, in many cases, the first traditional practice in HR was annual performance evaluation, as well as employee goals that "cascaded" down from business goals and unit goals each year. Since people worked on short-term projects of varying duration, often managed by different leaders and organized around teams, the notion that performance feedback would come once a year from a single boss made little sense. They need more, more, more people.

A first DAC survey found that people received less feedback and support when their employers refused annual reviews. However, this is because many companies do not put anything in its place. Managers did not feel an urgent need to adopt a new feedback model and shifted their attention to other priorities. But giving up grades without a plan to fill the void was, of course, a recipe for failure (Kaliyeva, 2018: 530). Since many organizations have learned this painful lesson, they have often conducted performance evaluations, usually on projects. This change has spread to several industries including retail (Gap), large pharmaceuticals (Pfizer), insurance (Cigna), investment (Oppenheimer Funds), consumer goods $(\mathrm{P} \& \mathrm{G})$ and accounting (BIG4). He is best known for in the GE, the various companies of the company and at IBM. Overall, the focus is on providing faster feedback throughout the year so teams can become more agile, "fix" bugs, improve performance, and learn through iterations-all vital 
principles of agile development. This methodology for obtaining quick feedback after each project execution process dramatically increases the efficiency and speed of the project. In Western practice, this is one of the tools to improve the efficiency of staff. In Kazakhstan companies, such experience exists on paper and General plans. However, such an assessment may not even be made. Since many companies, even foreign ones, have a well-formed vertical management system. Where the decisions of the top management are not subject to challenge, sometimes not submitted to the General review.

In a user-oriented manner, managers and employees have had a hand in shaping, testing and improving new processes. For example, the company Johnson \& Johnson has offered its companies to take part in the experiment: they could try the unique method of continuous feedback using a custom app using which employees, colleagues, and superiors can exchange comments in real time (Nathan, 1997: 53). The new process was an attempt to move away from J\&J's event-driven five-talk system (which focused on goal setting, career discussion, midyear performance review, year-end evaluation, and compensation review) and towards a model of an ongoing dialogue. Those who tried it asked him to tell me how it works, what errors and so on. The experiment lasted three months. At first, only $20 \%$ of managers in the pilot took an active part. The inertia of up to years of annual estimates was challenging to overcome. But then the company used the training to show managers what good feedback could look like, and appointed "Champions of change" to model the desired behavior in their teams. By the end of three months, $46 \%$ of the leaders of the pilot group had joined the group, exchanging 3,000 feedback. This method is beneficial from the constant maintenance of the teams and regulation of involvement of return of team members which helps to obtain positive results.

A dynamic biotech company Regeneron Pharmaceuticals goes further to overhaul their assessments. Michelle Weitzman-Garcia, Regeneron's head of human resources development, argues that the performance of scientists working on drug development, food group field sales, and corporate functions should not be measured on the same cycle or in the same way. She noted that these groups of staff needed different feedback and that they even worked on different calendars (Nathan, 2013: 230).

Thus, the company has created four separate assessment processes adapted to the needs of different groups. Research scientists and postdocs, for example, crave measurements and are interested in assessing competencies, so they meet with managers twice a year to evaluate competencies and review stages. Customer-oriented groups include customer and customer feedback in their assessments. While managing four separate processes complicates the job, they all reinforce the new norm of constant feedback. And Weitzman-Garcia says the benefits to the organization far outweigh the costs of HR. In Kazakhstan, most companies are not yet ready to determine such costs for HR.

Companies that most effectively implement Agile talent practices invest in honing the coaching skills of managers. Supervisors at Cigna undergo a" coach" training designed for busy managers: it is broken down into weekly 90 -minute videos that can be viewed when people have time. Managers also participate in training sessions, which, like the "training sprints" in agile project management, are concise and distributed to allow people to reflect and test new skills at work. Peer-to-peer feedback is also included in the training of Cigna managers: colleagues form training cohorts to share ideas and tactics. They have conversations that companies want executives to have with their direct reports, but they feel freer to share mistakes without fear of the "assessment" hanging over their heads. Henkel Kazakhstan has a training program for new professionals, where in short videos they get acquainted with products and brands. That saves labor and time for training. Also, such programs periodically include and update practices and videos to improve the competence of employees.

DigitalOcean, a New York-based startup focused on software as a service (SaaS) infrastructure, attracts a full-time professional coach on the spot to help all managers improve employee feedback and, more broadly, develop internal coaching capabilities. The idea is that once a person gets an excellent coaching experience, he becomes a better coach. Not everyone is expected to become great coaches-those in the company who prefer coding to coach can advance through a technical career, but coaching skills are considered Central to a managerial career. Kazakh national companies like Air Astana also invite professional coaches from abroad (London, Moscow) for staff training. On safety and application of new methods and business procedures. There is a training program for the onBoard team, where all beginners without exception are sent to the on-Board squad for training in Frankfurt. Where recruits are trained in flight safety and procedures (Nathan, 2012: 50).

$P \& G$ is also committed to making managers better coaches which is part of a more significant 
effort to restore training and development to managers and enhance their role in the organization. By simplifying the performance analysis process, separating evaluation from development discussions, and eliminating talent calibration sessions (the arbitrary horse trade between executives that often comes with a subjective and politicized ranking model), $P \& G$ has freed up a lot of time to devote to employee growth. But getting managers to move from evaluating employees to training them in their day-to-day work was not an easy task in a tradition-rich $P \& G$ culture. Thus, the company invested heavily in training managers on topics such as prioritizing and setting employee goals, how to provide feedback on contribution, and how to align employees ' career aspirations with business needs and training and development plans. Emphasis is on the fact that the creation of opportunities for staff and relationships with leaders will increase the engagement and therefore will help the company to innovate and move faster. Although the jury is still on all culture changes, P\&D has already noted improvements in these areas, at all levels of government which applies to all $\mathrm{P} \& \mathrm{G}$ offices, including the one in Almaty (Cahani, 2012: 49).

Traditional HR mainly focuses on people - their goals, their productivity, their needs. But now, with so many companies organizing their work project after project, their management systems and talents are becoming more team-oriented. Teams create, execute, and revise their goals and objectives using Scrum - at the team level, now, to adapt to new information as it becomes available ("Scrum" may be the most crucial term in flexible vocabulary. It comes from Rugby, where players pack tightly together to restart the game). They also take on the task of tracking their progress, identifying obstacles, assessing their leadership and generating ideas on how to improve productivity (Jeff Sutherland, 2017: 423).

In this context, organizations must learn how to deal with multidirectional feedback. The collection of feedback from colleagues is also essential for course adjustments and employee development in a flexible environment because team members know better than anyone else. Everyone is contributing which is rarely a formal process, and comments sent to the employee rather than the manager which saves a constructive contribution and prevents the undermining of colleagues, which sometimes happens more than a competitive workplace.

But some managers believe that feedback from colleagues should influence the assessment of performance. Diana Gerson, head of human resources at IBM, explains that the relationship between managers and employees changes in the context of the network [the collection of projects in which employees work]. Because a flexible environment makes it virtually impossible to "monitor" performance in the old sense, IBM managers request input from others to help them identify and resolve problems early. If it is not confidential, this input is used in daily group meetings and recorded in the application. Employees can choose whether to include managers and others in their comments to colleagues. The risk of destructive behavior mitigated by the fact that the team leader and expert comments. Anyone who tries to undercut colleagues will be exposed (Becker \& Gerhart, 1996: 790).

In flexible organizations, "bottom-up" feedback from staff to team leaders and managers is also highly appreciated. Mitre's nonprofit research centers have taken steps to encourage it, but they have found that it requires a focused effort. They started with periodic confidential interviews of employees and focused groups on finding out what issues people wanted to discuss with their managers. HR then distilled this data for executives to inform their conversations with direct reports. However, employees initially hesitated to provide feedback up, although it was anonymous and used only for development purposes because they were not used to expressing their thoughts on what management was doing.

Mitre also learned that the most critical factor in keeping subordinates honest was that managers directly said they wanted and appreciated comments. Otherwise, people might worry, reasonably, that their leaders weren't open to feedback and ready to apply it. Like any employee survey, getting feedback and not responding to it has a diminishing effect on participation; it undermines the vital trust between employees and their supervisors. When did the new process of performance management and feedback Mitre, the Director-General acknowledge that the research centers would need to repeat and improve? The revised feedback system will be implemented this year.

As team feedback spreads in all directions, many companies use technology to manage a considerable amount of it. Applications allow supervisors, colleagues, and customers to instantly share feedback wherever they are. It is imperative that managers can upload all comments later when it is time to make assessments. In some applications, employees and managers can measure progress toward goals; at least one of them helps managers analyze 
conversations on project management platforms like Slack to provide feedback on collaboration. Cisco uses proprietary technology to collect weekly raw data, or" breadcrumbs," from employees about the performance of their colleagues. Such tools allow managers to see fluctuations in individual performance over time, even within teams. Of course, applications do not provide an official record of performance, and employees may want to discuss issues face - to-face to avoid writing them to a file that can be downloaded. We know that companies recognize and reward improvement as well as actual performance; however, so hiding problems may not always pay off for employees.

\section{Results and discussion}

A fundamental shift towards teams has also affected decision-making rights: Organizations push them to the front line, equipping and enabling employees to work more independently. But this is a massive change in behavior, and people need support to make it happen. Now back to the example of the Bank of Montreal to illustrate how it can work. When BMO presented the agile team for the development of new services for clients, senior leadership was not quite ready to relinquish control, and the people under them are not accustomed to accepting it. Thus, the Bank has implemented agile coaches in business teams. They started with everyone, including high-level executives, going through "retrospectives" - regular reflection and feedback sessions held after each iteration which is a flexible version of post-action reviews; their goal is to continue to improve processes. As retrospectives quickly identified specific successes, failures, and root causes, senior executives at BMO immediately recognized their value, which helped them get on Board with agile in General and loosen their grip on decision making (Nathan, 2003: 3).

This method is also applicable for Kazakh companies, that is, hiring a professional coach and coach to identify shortcomings in a retrospective conversation for a more flexible and rapid response in the market. Regular discussions between teams and supervisors after each iteration, which will take no more than 10-15 minutes, will give an overview and improve the processes.

Finally, as the role of supervisor (leader) has moved away from simple personality management to the much more complicated task of promoting productive, healthy team dynamics, people often need help with that as well. A particular unit of Team Intelligence, Cisco provides such support. It aims to identify the most active teams in the company, analyze how they work, and help other groups learn how to become more like them. It uses team Space's enterprise platform, which tracks data about team projects, needs, and achievements to measure and improve what teams are doing in departments and the company. This aspect of team work is no less critical when planning teams and improving the efficiency of the company. The success of one group and the transparent methods of their success will allow other groups to keep up and take their tools and victory as a challenge. What is an essential component of human capital management throughout the company?

Table 1 - Agile methodology case studies

\begin{tabular}{|c|c|c|c|c|c|c|c|}
\hline $\begin{array}{c}\text { Organizations } \\
\text { in RK }\end{array}$ & Project & Purpose & Size & $\begin{array}{c}\text { HR transformation to } \\
\text { Agile }\end{array}$ & $\begin{array}{c}\text { Foreign } \\
\text { companies } \\
\text { already used } \\
\text { such practices }\end{array}$ & $\begin{array}{c}\text { Success } \\
\text { in using } \\
\text { Agile }\end{array}$ & $\begin{array}{c}\text { Success } \\
\text { in using } \\
\text { Waterfall }\end{array}$ \\
\hline Henkel CAC & $\begin{array}{c}\text { New } \\
\text { Talent and } \\
\text { Performance } \\
\text { management }\end{array}$ & $\begin{array}{c}\text { Knowledge } \\
\text { management }\end{array}$ & $\begin{array}{c}2000 \text { teams } \\
53000 \text { people } \\
80 \text { countries }\end{array}$ & $\begin{array}{c}\text { reduces financial } \\
\text { control from top to } \\
\text { bottom and gives teams } \\
\text { the ability to manage } \\
\text { projects themselves }\end{array}$ & BMO, GE & $79 \%$ & $50 \%$ \\
\hline Air Astana & $\begin{array}{c}\text { Digital } \\
\text { solutions } \\
\text { in Hr } \\
\text { management }\end{array}$ & Safety & $\begin{array}{c}200 \text { teams } \\
12 \text { countries } \\
\text { performance } \\
\text { panagement from the } \\
\text { perspective of teams, } \\
\text { not just individuals }\end{array}$ & Johnson \& & $88 \%$ & $35 \%$ \\
\hline
\end{tabular}


Agile methodology of human capital management

Continuation of table 1

\begin{tabular}{|c|c|c|c|c|c|c|c|}
\hline Samruk Kazyna & $\begin{array}{c}\text { Social } \\
\text { projects } \\
\text { development } \\
\text { Fund }\end{array}$ & $\begin{array}{c}\text { Process } \\
\text { improvement }\end{array}$ & $\begin{array}{c}750 \text { teams } \\
312400 \text { people } \\
358 \text { associated } \\
\text { companies }\end{array}$ & $\begin{array}{l}\text { rapid prototyping, } \\
\text { iterative feedback, team } \\
\text { solutions, and task- } \\
\text { oriented sprints }\end{array}$ & $\begin{array}{l}\text { IBM, Google, } \\
\text { CNN, Yahoo, } \\
\text { HSBC }\end{array}$ & $47 \%$ & $23 \%$ \\
\hline $\begin{array}{l}\text { JSC « national } \\
\text { infocommu- } \\
\text { nication holding } \\
\text { «Zerde» }\end{array}$ & $\begin{array}{l}\text { Public } \\
\text { private } \\
\text { partnership } \\
\text { project }\end{array}$ & $\begin{array}{c}\text { Process } \\
\text { improvement }\end{array}$ & $\begin{array}{c}3 \text { teams } \\
25 \text { people } \\
\text { Collocated }\end{array}$ & $\begin{array}{l}\text { establishing four } \\
\text { separate staff } \\
\text { assessment processes } \\
\text { adapted to the needs of } \\
\text { different groups }\end{array}$ & $\begin{array}{l}\text { Regeneron } \\
\text { Pharma- } \\
\text { ceuticals }\end{array}$ & $50 \%$ & $34 \%$ \\
\hline $\begin{array}{c}\text { JSC } \\
\text { «Accumulative } \\
\text { pension Fund } \\
\text { «GNPF.» }\end{array}$ & $\begin{array}{c}\text { Digital } \\
\text { system } \\
\text { operation } \\
\text { management }\end{array}$ & $\begin{array}{l}\text { Decreasing } \\
\text { expenses }\end{array}$ & $\begin{array}{l}25 \text { teams } \\
1176 \text { people } \\
\text { collocated }\end{array}$ & $\begin{array}{l}\text { bottom-up feedback } \\
\text { technique }\end{array}$ & Mitre, Cisco & $65 \%$ & $56 \%$ \\
\hline $\begin{array}{l}\text { Iplus education } \\
\text { center }\end{array}$ & $\begin{array}{c}\text { Opening of } \\
\text { new branches }\end{array}$ & $\begin{array}{l}\text { Case file } \\
\text { workflow/ } \\
\text { advertising }\end{array}$ & $\begin{array}{l}20 \text { teams } \\
140 \text { people } \\
\text { Collocated }\end{array}$ & $\begin{array}{l}\text { frequent performance } \\
\text { evaluations, by project } \\
\text { instant rewards system }\end{array}$ & $\begin{array}{l}\text { GAP, BIG4, } \\
\text { P\&G, Cigna, } \\
\text { Pfizer, etc }\end{array}$ & $87 \%$ & $60 \%$ \\
\hline Sberbank & $\begin{array}{l}\text { Creation of } \\
\text { a new HR } \\
\text { culture }\end{array}$ & $\begin{array}{l}\text { Innovative } \\
\text { direction }\end{array}$ & $\begin{array}{l}200 \text { teams } \\
6000 \text { people } \\
14 \text { countries }\end{array}$ & $\begin{array}{l}\text { investing in coaching } \\
\text { skills for managers, } \\
\text { having Scrum masters } \\
\text { in each business team }\end{array}$ & $\begin{array}{l}\text { Cigna, Digital } \\
\text { Ocean, BMO }\end{array}$ & $80 \%$ & $67 \%$ \\
\hline $\begin{array}{l}\text { KazNAU } \\
\text { university }\end{array}$ & $\begin{array}{l}\text { The course } \\
\text { for the } \\
\text { process } \\
\text { development }\end{array}$ & $\begin{array}{l}\text { Agile human } \\
\text { management }\end{array}$ & $\begin{array}{l}50 \text { teams } \\
5000 \text { people } \\
\text { collocated }\end{array}$ & $\begin{array}{l}\text { models of constant } \\
\text { dialogue with the team }\end{array}$ & $\begin{array}{l}\text { Johnson \& } \\
\text { Johnson, } \\
\text { Microsoft, } \\
\text { Intel }\end{array}$ & $82 \%$ & $65 \%$ \\
\hline
\end{tabular}

In Kazakhstan, the popularity of Agile methodology continues to gain momentum, and more and more companies are turning to flexible methods. Often, however, the Agile methodology is implementing without the necessary training and understanding the purpose of the implementation, and this leads to negative consequences. In addition to such common problems as the lack of involvement of the team or managers and the failure of project deadlines, there are other problems. For example:

- Burnout team;

- Reduced team performance;

- Customer expectations are not met, etc.

As seen in the table, the main difficulties are the corporate culture, which diverges from the principles of Agile component $63 \%$ of the survey, in second place with $47 \%$ - lack of knowledge and skills in the use of Agile methods. The lack of leadership lack of support methods is $45 \%$. The resistance of the organization is $43 \%$.

To eliminate the weaknesses of human capital management in Kazakhstan, it is necessary to introduce a flexible methodology in stages. Support for training, training, application of the above principles, recruitment methods and remuneration will also show positive results. It is necessary to develop mechanisms of interaction of transition to the Agile methodology for becoming more effective human resources management, contributing to improving the quality of human resources and business in General. Currently, a small part of the organization uses Agile methods in the management of organizations; mainly the application is observed in its projects. Organizations use only Agile tools or experiment on selected departments to use Agile management techniques. This approach in the world finds more and more fans in the project management environment. The modern world needs flexible and effective management. Most organizations in Kazakhstan have no idea of the effectiveness of Agile management practices. It is necessary to convey the essence of the approach and its advantages in managing not only projects but also the organization for a rapid response to the dynamic development of developing technologies in the world. Ministries planning to use Agile are recommended to pay attention to the international experience of agile implementation. Countries that have successfully implemented Agile started with pilot projects in the form of separate departments for digitalization. 
Nathan J. et al.

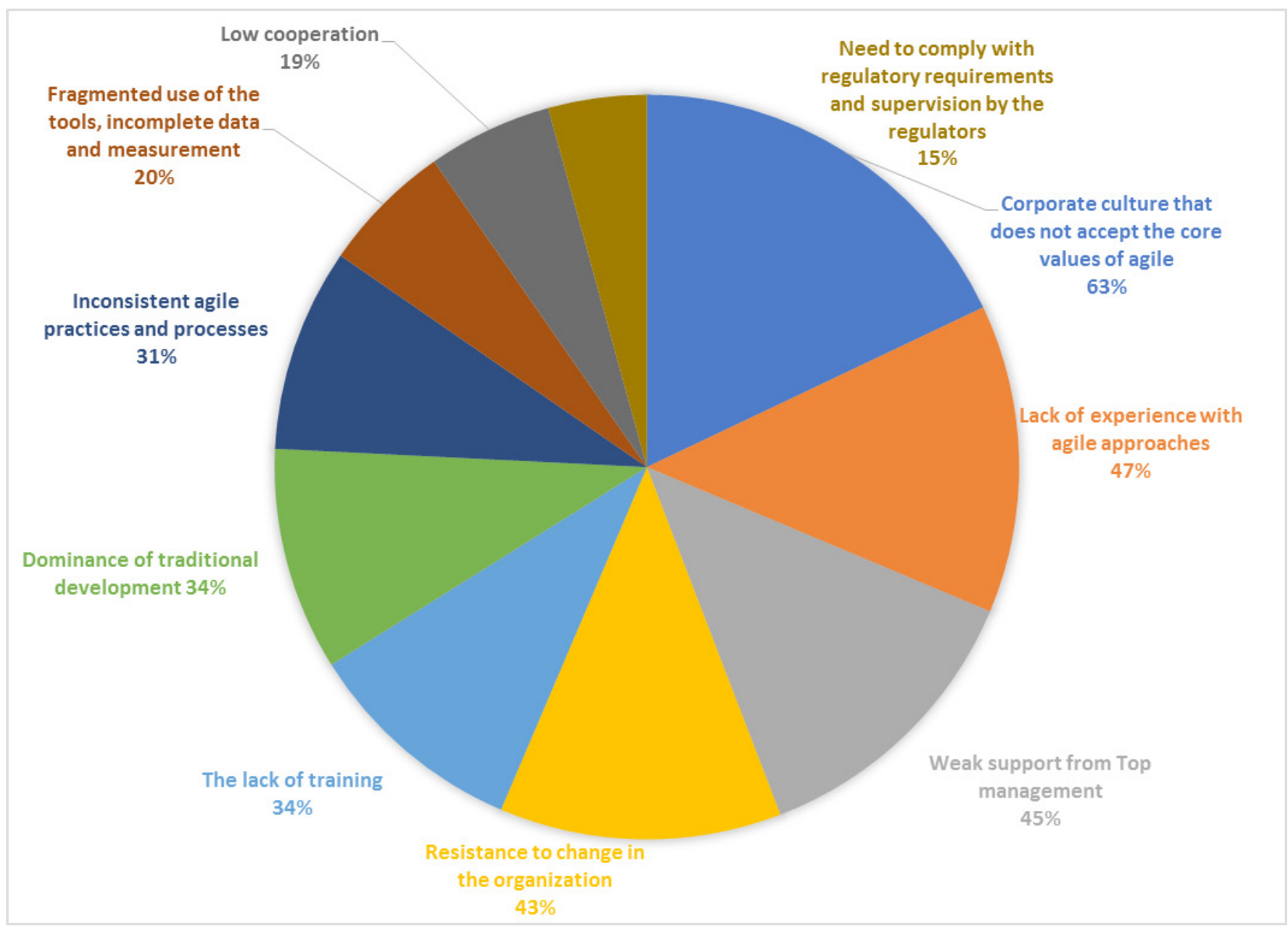

Figure 1 - Challenges in implementing and scaling Agile in Kazakhstan companies

Note-compiled by authors based on the source the official website of the Agile Alliance, 2018

\section{Conclusion}

It is recommended to start using the Agile management method with a pilot project, or departments responsible for digitization which will make them essential to change and allow them to adapt to rapidly evolving technologies. The time of dynamic development of technologies forces to act as flexibly as possible for successful management of projects and organizations. Using Agile methodology in government system need to start with project planning. In Kazakhstan, the budget planning of projects takes an average of 2 years, and in General for the implementation of 3-4 years. While planning and budgeting are under way, development technologies and methods are becoming obsolete. As a result, before the final stage of the project, in our case, the service, there are changes in the technological and legislative plan. On average, it takes $4-5$ years to put the product into operation in the form of an electronic service. At the same time, during this time there can be only the prototype of the service. The problem is the lack of project approach in the planning and budgeting of projects, many coordinating organizations, the requirement of feasibility studies for all projects.

Of course, not every organization or group strives for rapid innovation. Some tasks should remain mostly rule-based. In such cases, flexible talents may not make sense. And even when they are relevant, they can meet resistanceespecially in HR. Many processes must change, the organization moved away from the model of "waterfall" - based planning (which is linear and not flexible and adaptive), and some of them embedded in information systems, job titles, etc. the Transition to cloud it, which is independent, has simplified the implementation of tools based on applications. But people's problems remain a stumbling block. Many HR tasks, such as traditional recruitment approaches, adaptation, and programmed coordination, will become obsolete, as will experience in these areas. In the meantime, new tasks are created. Helping managers replace 
refereeing with coaching is a big challenge not only in terms of skills but also because it undermines their status and formal credibility. Shifting control focus from individuals to teams can be even more difficult because team dynamics can be a black box for those still trying to figure out how to coach people. The big question is whether companies can help managers take it all on and see the value in it.

The HR function will also require re-filling. $\mathrm{He}$ will need more experience in its support, especially given all the performance data generated by new applications and more in-depth knowledge of teams and hands-on control. HR has not had to change in recent decades almost as much as the linear operations it supports. But now the pressure is mounting, and it's coming from the operational level, making it much harder to cling to old talent practices. The human resources management system based on the Agile methodology shows the effectiveness of the existing methods in the world, while the existing ones are more expensive and inefficient. Along with this, it is necessary to consider the peculiarities of socio-economic development of the country, modern trends, phenomena, processes. And to ensure that the natural resources of our country provide the necessary reserve of economic strength, it is needed to use the best Kazakhstan and international experience in the field of flexible human resource management. Using only Agile attributes and methods will not produce substantial results. Great results will be achieved with flexible or Agile thinking and well-established management, as well as with changes in the corporate culture of organizations.

\section{References}

1 Бахмутов О. Agile подход - бизнес без «бюрократии» // Курсив. - 2017, https://kursiv.kz/news/vlast-i-biznes/2017-02/ agile-podkhod-biznes-bez-byurokratii

2 Kaliyeva S.A., Zharkymbekova K.B. The Need for Qualified Personnel in Order to Increase the Efficiency of the Youth Labor Market Operation // The Academy of Management and Administrationin Opole. - 2015. - vol. 5. - no 3, pp. 157-167.

3 Калиева С.А., Мелдаханова М.К. Механизм регулирования занятости в условиях глобализации экономики / в сборнике Казахстан 2050 в условиях десяти глобальных вызовов 21 века. - 2015, С. 177-196.

4 Kaliyeva S.A., Sadykov I.M. Precarization of employment: main forms and its impact on the society / Материалы 15 международной научно-практической конференции, Прага, Чешская Республика. - 2016, pp. 249-253.

5 Nathan J. Kazakhstan's New Economy, Post-Soviet, Central Asian Industries in Global Era. - University of Scranton Press, Pennsylvania. - 2013, $230 \mathrm{p}$.

6 Nathan J., Cahani. The Republic of Kosovo, Surviving, Sustaining, and Succeeding in the Balkan Peninsula // Journal of Global Awareness. - 2012. - vol. 12, pp. 49-51

7 Nathan J. Kazakhstan`s Oil Supply Chain Management Challenges // Review of Business. - 2008, pp. 13-21.

8 Nathan J. A Historical Perspective on the Value Paradoxes in Kazakhstan // Journal of Global Awareness. - 2004. - no 2. vol. 5, pp. 44-48.

9 Nathan J. Paradoxes of Nation States in the Global Era // Exclusive Review. - 2004. - no 4. - vol. 13, pp. 32-33.

10 Nathan J. Total Quality Management Integrates Business and Education // Central Asian Management Journal. - 2003. - no 5. - vol. 20, pp 1-5.

11 Sutherland J. Scrum Revolutionary project management method. - 2017.

12 Novikov D.A. The methodology of scientific research, -2010.

13 Barney J. Looking inside for competitive advantage // Academy of Management Executive. - 1995. - no 9. - vol. 4, pp. 4961 .

14 Bartel A.P. Productivity gains from the implementation of employee training programs // Industrial Relations. - 1994. no 33, pp. 411-425.

15 Becker B., Gerhart B. The impact of human resource management on organisational performance: Progress and prospects // Academy of Management Journal. - 1996. - no 39, pp. 779-801.

16 Delaney J.T., Huselid M.A. The impact of human resource management practices on perceptions of organizational performance // Academy of Management Journal. - 1996. - no 39, pp. 949-969.

17 Lalu F. Otrkivaysa organizacii budushego. - 2017, 2 edition.

18 Arthur J.B. Effects of human resource systems in manufacturing performance and turnover // Academy of Management Journal. - 1994. - no 37, pp. 670-687.

19 Arthur J.B. The link between business strategy and industrial relations systems in American steel minimills // Industrial and Labor Relations Review. - 1992. - no 45, pp. 488-506.

20 Trinkaus J., Nathan J. Acetaminophen (Tylenol): Johnson\&Johnson and Consumer Safety // Journal of Law, Medicine \& Ethics. - 1997. - no 1. - vol. 25, pp. 49-57

21 11-й ежегодный отчет State of Agile, VersionOne, https://forbes.kz/process/resources/nujnyi_li_kazahstanu_upravlencheskie_kolodtsyi 


\section{References}

$111 \mathrm{i}$ ezhegodnyi otchet State of Agile [11th annual report State of Agile]. VersionOne, https://forbes.kz/process/resources/ nujnyi_li_kazahstanu_upravlencheskie_kolodtsyi

2 Arthur J.B. (1992) The link between business strategy and industrial relations systems in American steel minimills. Industrial and Labor Relations Review, no 45, pp. 488-506.

3 Arthur J.B. (1994) Effects of human resource systems in manufacturing performance and turnover. Academy of Management Journal, no 37, pp. 670-687.

4 Bahmutov O. (2017) Agile podhod - biznes bez "byurokratii" [Agile approach - business without "bureaucracy"]. Kursiv, https://kursiv.kz/news/vlast-i-biznes/2017-02/agile-podkhod-biznes-bez-byurokratii

5 Barney J. (1995) Looking inside for competitive advantage. Academy of Management Executive, no 9, vol. 4, pp. 49-61.

6 Kaliyeva S.A., Meldahanova M.K. (2015) Mehanizm regulirovaniya zanyatosti v usloviyah globalizacii economiki [Mechanism of employment regulation in the context of globalization of the economy], v sbornike Kazakhstan $2050 \mathrm{v}$ usloviyah desyati globalnyh vyzovov 21 veka, pp. 177-196.

7 Kaliyeva S.A., Sadykov I.M. (2016) Precarization of employment: main forms and its impact on the society. Materialy 15 mejdunarodnoi nauchno-praktichaskoi konferencii Praga, Cheshskaya Respublica, pp. 249-253.

8 Kaliyeva S.A., Zharkymbekova K.B. (2015) The Need for Qualified Personnel in Order to Increase the Efficiency of the Youth Labor Market Operation. The Academy of Management and Administrationin Opole, vol. 5, no 3, pp. 157-167.

9 Nathan J. (2003) Total Quality Management Integrates Business and Education. Central Asian Management Journal, no 5, vol. 20, pp. 1-5.

10 Nathan J. (2004a) A Historical Perspective on the Value Paradoxes in Kazakhstan. Journal of Global Awareness, no 2, vol. 5, pp. 44-48.

11 Nathan J. (2004b) Paradoxes of Nation States in the Global Era. Exclusive Review, no 4, vol. 13, pp. 32-33.

12 Nathan J. (2008) Kazakhstan`s Oil Supply Chain Management Challenges. Review of Business, pp. 13-21.

13 Nathan J. (2013) Kazakhstan's New Economy, Post-Soviet, Central Asian Industries in Global Era. University of Scranton Press, Pennsylvania, 230 p.

14 Nathan J., Cahani (2012) The Republic of Kosovo, Surviving, Sustaining, and Succeeding in the Balkan Peninsula. Journal of Global Awareness, vol. 12, pp. 49-51

15 Novikov D.A. (2010) The methodology of scientific research

16 Sutherland J. (2017) Scrum Revolutionary project management method.

17 Trinkaus J., Nathan J. (1997) Acetaminophen (Tylenol): Johnson\&Johnson and Consumer Safety. Journal of Law, Medicine \& Ethics, no 1, vol. 25, pp. 49-57 